\title{
明治から昭和初期における熊本県及び市の建築指針と建設実態 小学校の南側廊下校舎に関する研究 \\ BUILDING GUIDELINE OF KUMAMOTO PREFECTURE AND CITY AND THE CONSTRUCTION ACTUAL CONDITION
}

A study on the elementary school building with a south-side corridor

$$
\text { 秋 元一秀* }
$$

\section{Kazuhide AKIMOTO}

\begin{abstract}
This study aims to clarify the actual condition and the background of the elementary school building with a south-side corridor in Kumamoto prefecture from Meiji to the early stages of Showa. Findings are follows: 1) In the guideline of the elementary school building, Kumamoto prefecture showed the standard about the arrangement composition and the form of the school building earlier than the government. 2) The tendency which follows the guideline of the government or prefecture was seen in the arrangement composition and the form of school buildings. 3) Although it was said that Kumamoto prefecture insisted on the south-side corridor in a school building, numbers of that building were few and their rate of a north-side corridor increased as time passes. However, at the southern prefecture area and centering on Kumamoto, there were many school buildings with a south-side corridor, so regionality was seen. 4) At the beginning of Taisho, the Kumamoto prefecture changed to the guideline to leave it to judgment of each corporation. Kumamoto city recommended the south-side corridor, and accordingly school building with a south-side corridor increased after that.
\end{abstract}

Keywords: south-side corridor, elementary school, Kumamoto prefecture, regionality, judgment of corporation 南側廊下, 小学校, 熊本県, 地域性, 自治体の裁量

\section{1 目的と方法}

\section{1 目的}

小学校の校舎の多くにみられる北側廊下の形式は、明治中期以降、 文部行政主導のもと拡大し定着していった。その経緯に関しては、 既往文献 ${ }^{1)}$ において、「小学校令」等の法制度の整備過程を軸とし て解明されている。また、こうした流れの中で、三島氏は明治 24 年以降の九州・奥羽・四国山陽地方における学校衛生の取り調べを もとに、西南地方の学校において南側廊下を設ける傾向があること を指摘しており注 1)、さらに、青木氏は熊本・高知両県が南側廊下を 主張していたと述べている注2)。

小学校は地域に密着した教育施設で、地域の実情に即して独自の 改変・改善を重ねて今日に受け継がれてきたはずと、大場氏が指摘 しているように注3)、地域ごとの実情をくみ取ったうえで、小学校校 舎の形成過程を検討する試みはいまだ少ない ${ }^{5 \sim 12)}$ 。先に述べた南側 廊下を主張したとされる熊本・高知両県の実態に関する研究として は、山本氏の大正 12 年に建設された熊本県八代市の代陽小学校に関 する報告 ${ }^{13)}$ があるのみである。尚、この小学校の校舎は南側廊下で あり 注4)、また、同時期以降に熊本市で建設された小学校でも南側廊 下の校舎がみられた注5)。
ところで、明治 33 年の「小学校令」の改正にともない、小学校の 設置、新築・増改築に際して知事が認可を与えることになり注 6$)$ 、熊 本県が所蔵している県政資料 ${ }^{15)}$ の中に、明治 44 年から大正 7 年に かけてのそうした届け出の文書が図面とともに残されている。また、 同時期の熊本市では、議会において小学校建設に関する案件が審議 されている注7)。

本研究では、これらの史料をもとに当時の熊本県における小学校 校舎の配置構成及び校舎形態の特徵を明らかにするとともに、南側 廊下校舎を持つ小学校に関しては、その建設年代ごとの政府、県及 び市の小学校建築に対する指針との関係からその背景を明らかにす ることを目的とする。

\section{2 方法}

まず、既往文献 1)、2)、17) から明治以降大正にかけての小学校建築 に対する指針を政府と熊本県それぞれにおいて把握し、特に校舎の 配置及び平面構成に関する熊本県の特徵を明らかにする。

\section{表 1 県政資料掲載小学校届出概要}

\begin{tabular}{|c|c|c|c|c|c|c|c|}
\hline 届出内容 & 新築 & 移築 & 増·改築 & 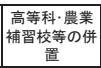 & 拡張·地 & $\begin{array}{c}\text { 施設以外 } \\
\text { の届出 }\end{array}$ & 計 \\
\hline 小学校数 & 8 & 3 & 61 & 81 & 14 & 8 & 175 \\
\hline
\end{tabular}


次に、県政資料に掲載されていた小学校を、当時の県下の小学校 数及び立地する地域からその偏りを確認する。尚、対象とした県政 資料の届け出の中で、図面が掲載されていた小学校数は 175 校であ

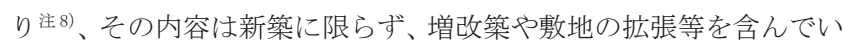
た(表 1)。これらの配置及び平面図を通して、当時の学校建築に対 する課題の中から校舎の配置構成及びその形態、並びに、校舎にお ける廊下位置に関して、その特徵を新築のものとそれ以外との比較 を踏まえ明らかにし、南側廊下校舎をもつ小学校の実態、並びに、 小学校建築に対する政府と県の指針との対応関係を考察する。

さらに、南側廊下校舎を持つ小学校に対しては、建設の経緯をそ れぞれの学校史等から把握し、大正期以降も南側廊下校舎の建設が みられる熊本市における小学校校舎の廊下位置の実態を学校史等に 掲載されている平面図から明らかにするとともに、その背景に関し て市議会録 ${ }^{16)}$ 等から考察を加える。

\section{2 明治期の熊本県における小学校建築に対する指針と建設実態}

\section{1 小学校建築に対する指針と熊本県の特徵}

政府及び熊本県における法令 ${ }^{2)}$,17)、18) から、特に校舎の配置構成、 校舎形態、並びに、校舎における廊下位置に関する指針を把握する (表 2)。
まず、小学校建築に顕著な影響を及ぼす契機となったといわれる 明治 19 年の政府による「小学校令」、同 23 年の「小学校令」改正とそ の細則のひとつである同 24 年の「小学校設備準則」では、校舎の配置 構成等に関しては触れられていない。一方、熊本県は翌 25 年「小学 校設備規則」において、『校舎八成ルヘク東西二長ク南北ニ短キヨ要 ス』や『校舎八光線ノ注射空気ノ流通二便ナルヨ要ス』とあり、校 舎形態や教室における採光・通風へ考慮する内容を含んでいる。

明治 28 年には文部省会計課建築掛が「学校建築図説及び設計大 要」において、配置構成として、体操場はなるべく敷地の南または 東に位置することを奨め、校舎形態では長方形・凸凹形・工字形を推 奨し、また、廊下に関することでは中廊下を避け、教室の向きは南 または西南・東南を良しとしている。一方、熊本県は翌 29 年に「小 学校建築標準」において、配置構成及び校舎形態に関して『校舎八 敷地ノ北方ニ建ツルヨ良卜ス若シ北二建テ難キハ西北建ニツル要 ス』、『校舎八長方形ニシテ南ニ向ハシムベシ、数棟ノ校舎ヨ要スル モノ八四間乃至五間ヨ距テ、同形ノモノタ並列シ凹字形、回字形、 肱股形等八之ヨ避クルヨ要ス』とあり、北側校舎・南側運動場の配 置構成、並びに、校舎の南面化と並列配置を推奨していることが確 認できる。また、廊下に関しては、『廊下八室外二設ケ其幅八六尺以 上トスルヨ要ス』とある。

表 2 明治から大正初期における政府及び熊本県の小学校建築に対する指針

\begin{tabular}{|c|c|c|c|c|c|c|c|c|c|c|c|c|c|c|c|c|}
\hline & \multirow{2}{*}{$\begin{array}{l}\text { 明治15年 } \\
\text { 文部省示諭 }\end{array}$} & \multirow{2}{*}{$\begin{array}{l}\text { 明治23年 } \\
\begin{array}{c}\text { 小学校令 } \\
\text { (改正) }\end{array}\end{array}$} & \multirow{2}{*}{\begin{tabular}{|l|} 
明治24年 \\
小学校 \\
設備準 \\
則
\end{tabular}} & \multirow{2}{*}{\begin{tabular}{|c} 
明治25年 \\
$\begin{array}{l}\text { 小学校設備規則 } \\
\text { (熊本 }\end{array}$
\end{tabular}} & \multirow{2}{*}{\begin{tabular}{|l}
\multicolumn{1}{|c}{ 明治28年 } \\
学校建築図 \\
説明及ひび設 \\
計大要
\end{tabular}} & \multirow{2}{*}{\begin{tabular}{|c|c} 
明治29年 \\
熊本県訓令 \\
小学校建筑標準
\end{tabular}} & \multirow{2}{*}{$\begin{array}{l}\text { 明治32年 } \\
\\
\text { 小学校設備 } \\
\text { 準則改正 }\end{array}$} & \multirow{2}{*}{\begin{tabular}{|l}
\multicolumn{1}{|c}{ 明治32年 } \\
小学校設備 \\
上の注意訓 \\
令
\end{tabular}} & \multirow{2}{*}{\begin{tabular}{|c|c} 
& 明治 32 年 \\
小学校設備規則 \\
改正 \\
(熊本県)
\end{tabular}} & \multirow{2}{*}{\begin{tabular}{|l|} 
明治33年 \\
小学校令施行規 \\
則
\end{tabular}} & \multirow{2}{*}{\begin{tabular}{|c|} 
明治33年 \\
小学校令施行に \\
閶するる規定 \\
(熊本県 \\
県令第百号)
\end{tabular}} & \multicolumn{2}{|c|}{ 明治37年 } & \multirow{2}{*}{\begin{tabular}{|l|}
\multicolumn{1}{|c}{ 明治41年 } \\
小学校令施 \\
行規則改正 \\
(熊本県 県令 \\
第九号)
\end{tabular}} & \multirow{2}{*}{$\begin{array}{l}\text { 大正2年 } \\
\text { 小学校令 } \\
\text { 施行規定 } \\
\text { (態本県県 } \\
\text { 令第五号) }\end{array}$} \\
\hline & & & & & & & & & & & & & 学校建築設計要項 & (小学校) & & \\
\hline \multicolumn{2}{|c|}{ 敷地 } & 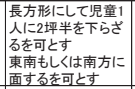 & & $\begin{array}{l}\text { 校地は日 } \\
\text { 当たり好 } \\
\text { く.・ }\end{array}$ & 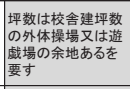 & $\begin{array}{l}\text { 校舎の敖地は } \\
\text { 生徒人1に付 } \\
\text { 坪以上 }\end{array}$ & & & & & & & & 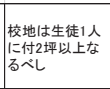 & & \multirow{3}{*}{ 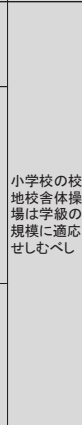 } \\
\hline & 配置 & & & & & $\begin{array}{l}\text { 体㙅場は成るべ } \\
\text { 教地の南方丈 } \\
\text { は東方の位蹎 } \\
\\
\end{array}$ & 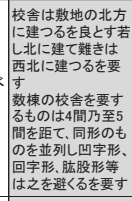 & & 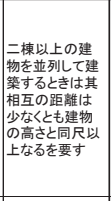 & 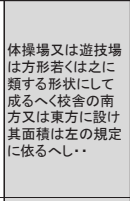 & & & 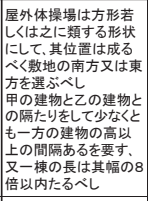 & & & \\
\hline & 挍舎 & 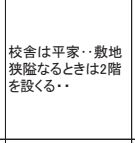 & 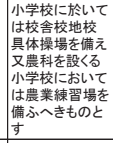 & なる゚く平 & 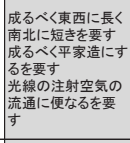 & 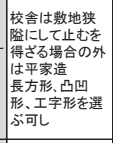 & 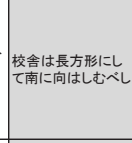 & 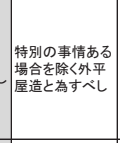 & & $\begin{array}{l}\text { 校舎は成るへく平 } \\
\text { 造とし }\end{array}$ & 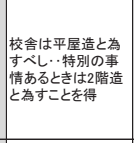 & 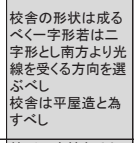 & 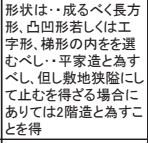 & & & \\
\hline \multicolumn{2}{|c|}{ 平面計画 } & 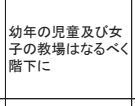 & & \begin{tabular}{|l} 
2階造なる \\
ときはなる \\
穴幼年生 \\
の教室を \\
階下に
\end{tabular} & 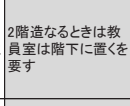 & & 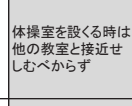 & & & 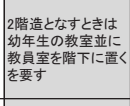 & & 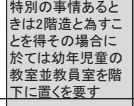 & & & 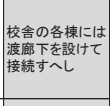 & \\
\hline \multirow{4}{*}{$\begin{array}{l}\text { 諸 } \\
\text { 室 } \\
\text { 計 } \\
\text { 画 }\end{array}$} & $\begin{array}{l}\text { 教室 } \\
\text { 教場 } \\
\end{array}$ & 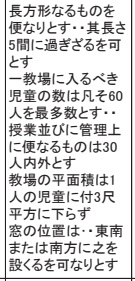 & & & & 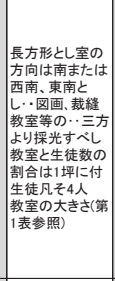 & 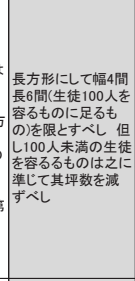 & 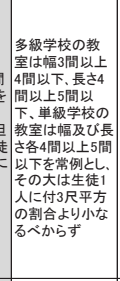 & 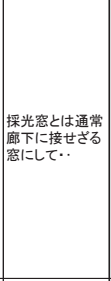 & 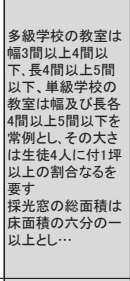 & 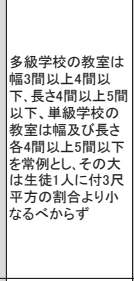 & (同左) & 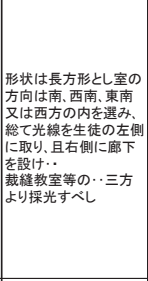 & 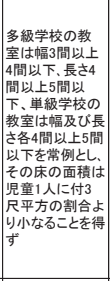 & 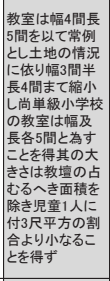 & \\
\hline & 廊下 & & & & & 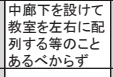 & 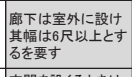 & 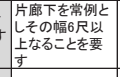 & \begin{tabular}{|l|} 
版店下と為すを \\
常列とす
\end{tabular} & 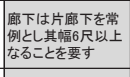 & 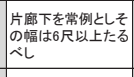 & 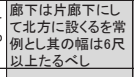 & 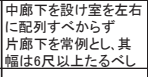 & & & \\
\hline & 杽降 & 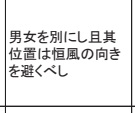 & & & & & 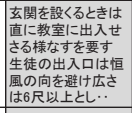 & $\begin{array}{l}\text { なるベく男女を } \\
\text { 区乱常風のう方 } \\
\text { 向を避さぐ゚し }\end{array}$ & & 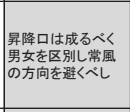 & 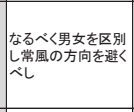 & (同左) & 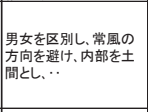 & & & \\
\hline & $\begin{array}{l}\text { その } \\
\text { 他 } \\
\text { 諸室 }\end{array}$ & 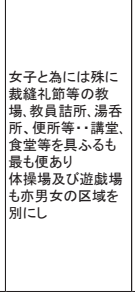 & & & $\begin{array}{l}\text { 嘋員室及び生徒 } \\
\text { 等作 }\end{array}$ & 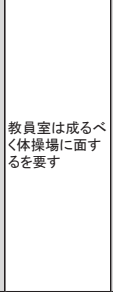 & & 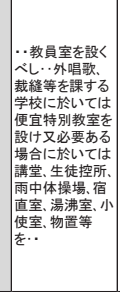 & 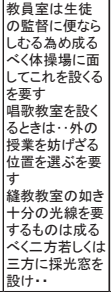 & & 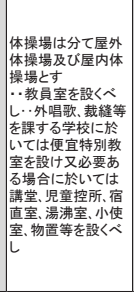 & (同左) & 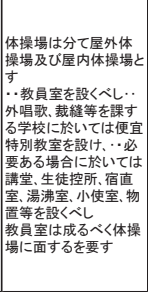 & & & \\
\hline
\end{tabular}


明治 32 年に、政府は「小学校設備準則改正」及び「小学校設備上 の注意訓令」により、2 棟以上の建物を並列して建築する場合の隣 棟間隔や、片廊下を常例とし、教室の採光空は廊下側の空としない などの内容が加わっている。一方、熊本県でも同年「小学校設備規 則改正」を示しており、その内容は政府の指針の大部分をとり入れ たものとなっている。これは政府の「小学校設備準則改正」の再改 正であり、その理由として『本県小学校教育ノ実質八稍進歩ノ好況 ヨ呈スルモ其設備ニ至ッテハ他府県ニ比シル下位二班ス』と、熊本 県における小学校建築のレベルの低さが指摘されており注9)、それま での県の指針において、配置構成や校舎形態に関する規準が政府よ りいち早く示されていながら、いまだ浸透していなかったことが窅 える。また、その翌年、「小学校設備準則改正」に再び若干の改訂が 加えられ、「小学校令施行規則」の中に加えられるが、県でもそれを 受けて県令「小学校令施行に関する規定」が示された。その内容の 多くは政府のものと同様であるが、校舎形態に関しては『校舎ノ形 状八成ルヘク一字形若八二字形トシ南方ヨリ光線ヨ受クル方向ヨ選 フヘシ』が、廊下では『片廊下ニシテ北方二設クルヨ常例トシ』が 加えられている。三島氏が明治 34 年の官報「校舎衛生上ノ利害調査」 注 10) において、廊下位置の論争に対し、北側廊下の優位を決定づけ たが、熊本県ではその前年に北側廊下校舎を推奨していることは注 目すべき点である。尚、九州日日新聞注 11) によると、三島氏は明治 24 年 10 月 23 日より 26 日にかけて学校衛生の取り調べのため熊本 県を訪れており、市内の小学校では尋常一新小学校と同碩臺小学校 を巡視し、同年 10 月 27 日付の新聞では、一新小学校に対して『 $\cdots$ 一通り衛生の道にかなひ校舎の建築も頗る法に適して先ず可なりの 構造なるか…』とあり、衛生上問題なかったとことが示されている。

明治 37 年には、建築掛が「学校建築図説及び設計大要」を改訂増 補した「学校建築設計要項」を刊行するが、体操場や便所等に関す る規定が加わる程度にとどまっている。その後、熊本県でも改正は 行われてはいるものの、明治 41 年に教室の大きさに関して『…地 ノ情況二依リ幅 3 間半長 4 間マテ縮小シ…』が加えられる程度で、 地域の状況を配慮する旨の内容が示され、大正 2 年には『小学校 校地校舎体操場八学校ノ規模二適応セシムベシ』の1条にし、それ まで行ってきた詳細な規定をなくし、関係当事者の裁量に任せると いう方針をとった。この背景に関しては、県内の小学校の設備が改 善されたことと明治 42 年の文部省の訓令との関係が推測される。熊 本県では、明治 35 年に小学校の設備を完備する旨の訓令と同 40 年 に同様の指示が出され、以降大正 2 年までに小学校全体の約 7 割で 新築あるいは増改築が行われ、その結果、小学校建築の状況が一新 したとのことである注 12$)$ 。また、明治 42 年の文部省の訓令「学校校 舎ノ建築八実用 主トスヘキ件」注13) では『…律一様ノ校舎 ヨ造 ルノ弊ヨ生シ…土地ノ状況习参酌シテ常ニ実用ヨ主トシ努メテ地方 ノ民カニ伴ワシメンコトヨ記セラルヘシ』と、地域の実情に応じた 施設計画を求めていることから、県下の小学校の設備改善と相まっ た上での方針と考えられる。

\section{2 明治大正期の建設実態と建築的特徵}

明治 10 年以降の熊本県における小学校数の推移をほぼ 10 年おき にみる。時代ごとに史料は異なるが注 14)、小学校が設立され始めた 明治 10 年頃を除き、ほぼ 600 校前後で推移していることがわかる。 本研究で対象とする県政資料掲載の小学校数を大正 2 年のものと比
較すると、ほぼ 3 割にあたる。地域ごとでは、一番割合の高い球磨 郡で $69.8 \%$ にあるのに対し、低いものでは阿蘇郡の $14.9 \%$ 、八代 郡の $16.3 \%$ とやや開きがあるが、それ以外の地域では 25〜 45\%で、 全体における割合と同程度となる(表 3 )。

以下、玉名、山鹿、山本、菊池、合志、阿蘇郡を北部、上益城、 飽田、託麻郡と熊本区を中部、下益城、宇土、天草、八代、芦北郡 を南部、球磨郡を球磨地方として、地域性を踏まえながら建築的特 徵を捉える注 15)。

敷地規模は、全体としては 800 坪未満、800 坪以上 1600 坪未満、 1600 坪以上がそれぞれほぼ $1 / 3$ ずつを占めている。地域ごとにみ ると、球磨地方では全体と同様の分布を示し、南部地方では 800 坪 未満が約半数を占めるのに対し、北部及び中部ではそれぞれ $25 \%$ と $20 \%$ で、北部では 1600 坪以上が $37 \%$ 、中部では 800 坪以上 1600 坪 未満が $47 \%$ となり、南部地方では敷地規模の小さいものが、北部及 び中部地方では大きいものが多くを占める傾向を示した(図 1)。

校舎規模を延床面積からみると、全体としては 200 坪未満及び 200 坪以上 400 坪末満が 4 割弱、400 坪以上が 2 割強を占めた。地方ご とには敷地規模と同様の傾向を示し、球磨地方では全体と同様な分

表 3 県政資料揭載小学校の地域的分布

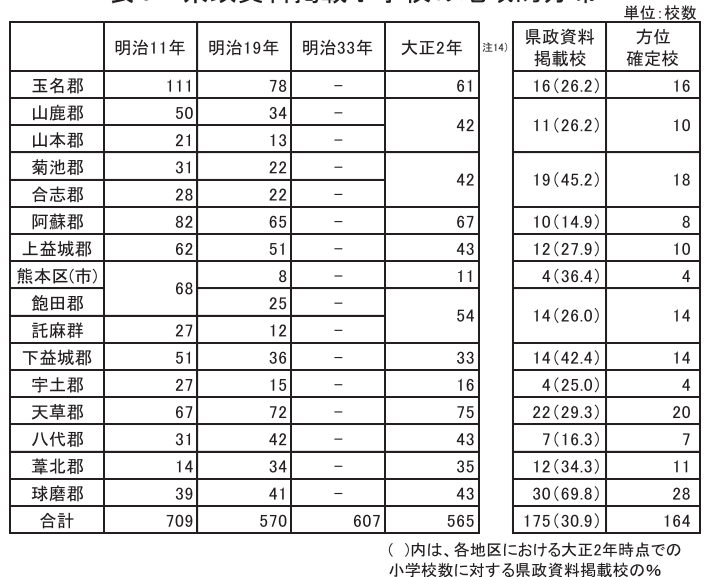
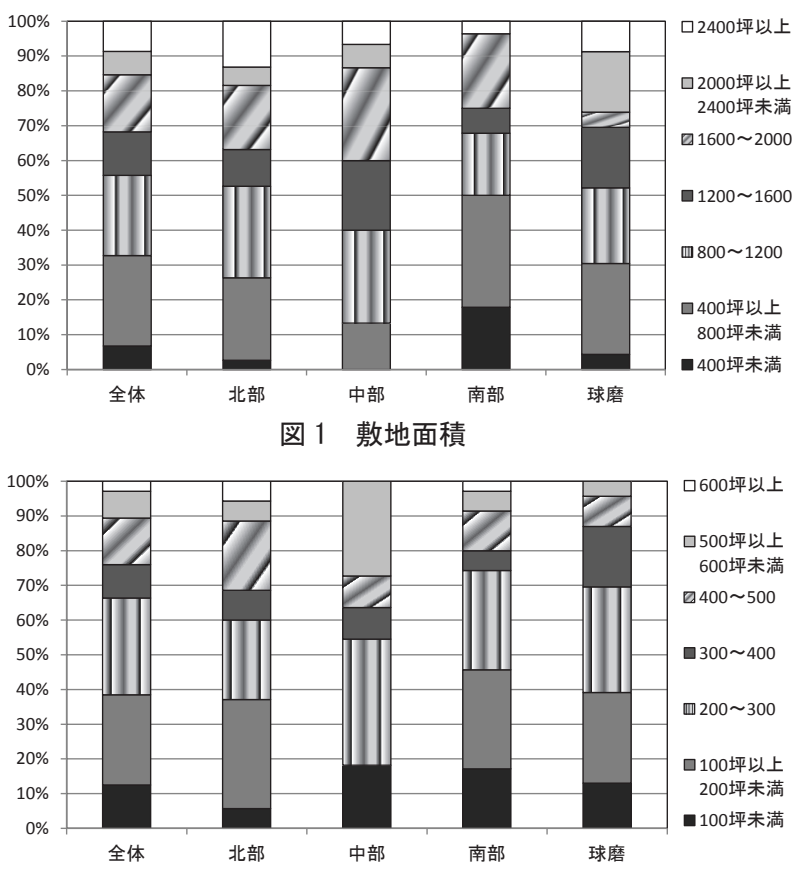

図 2 校舎延床面積 
布で、南部地方では規模の小さいものが、北部及び中部地方では大 きいものの割合が高く、特に中部では 200 坪を超えるものが 8 割強 を占め、400 坪を超えるものも $45 \%$ にのぼった(図 2)。

敷地規模、延床面積と校舎形態の関係をみると、校舎形態は概ね 延床面積との対応関係が見られた。延床面積が 300 坪未満の場合は 49 校中 34 校が一列型と約 7 割を占め、200 坪を超えると、L 字型、 コ字型、並列型がみられるようになり、特に規模が大きくなるほど 校舎が平行に並ぶ並列型が卓越してくることが確認できる(図 3)。

方位に着目し、校舎と運動場の位置関係、校舎形態及び廊下位置 に関して、明治 44 年から大正 7 年にかけて新築された小学校とそれ 以前に建てられたものの比較を踏まえて、それぞれの特徴を述べる。

校舎と運動場の位置関係に関しては、共通して北側校舎·南側運動 場の形態が多く、新築で $75 \%$ 、それ以外のもので $68 \%$ を占める。残 りは、新築では東・西あるいは西・東の配置になるのに対し、それ以 外のものでは南側校舎・北側運動場や囲み型の配置など様々な形態 がみられた。配置構成に関しては、政府と県がそれぞれ明治 28 と 29 年に、校舎を敷地の北もしくは西に配置するよう推奨しているこ とから、それと対応した傾向が確認できた(図 4)。

校舎形態は共通して一列型が 4 割弱と一番多く、続いて並列型、 L 字型となり、それぞれの割合は新築がそれ以外に比べ高く、並列型 ではそれ以外が $32 \%$ であったのに対し新築では $38 \%$ に、 L字型でも $16 \%$ から $25 \%$ 一と上昇している。明治 28 と 29 年の政府及び県の指 針では、長方形もしくは凹凸型、工字型を推奨していることから、 それを遵守する傾向がみられた。届け出より前に建てられていた小 学校ではコの字型やそれ以外の形態も $15 \%$ を占めるが、その中には 増築等の結果、そうした配置構成になったものも含まれる(図 5)。

廊下位置に関しては北側か南側かに着目寸るため、複数の廊下が 存在する場合は、北側と南側の両方とも存在するものと、それぞれ どちらかだけに東もしくは西側の廊下がつくものに分類する(表 4)。 新築では全て “北側廊下”であり、新築以外でも $3 / 4$ を占め、“南 側廊下”、並びに、“北+南側廊下”は、ほぼ 1 割ずつであった。南側 廊下の校舎をもつ小学校は 28 校で、全体の $18.1 \%$ にあたるが、地 域的にみると、山鹿郡・山本郡、玉名郡、阿蘇郡、宇土郡では 1 校 もみられないのに対し、飽田郡と託麻郡が合併した飽託郡で 38.5\%、 球磨郡と熊本市で $33.3 \%$ 、八代郡で $28.5 \%$ を占め、熊本市とその周 辺及び県南で高い割合を示した。政府は明治 28 年に教室の方向を南 または西南・東南に、県は同 29 年に校舎は南向きに、さらに、政府 は同 32 年に採光空に関して廊下に接する空にしないようにとあり、 県では同 33 年の県令で北側廊下を推奨している。熊本県全体の状況 は、こうした指針に従った結果とみることができる。一方、南側廊 下を主張していたという点に関しては、県全域でそれを裏付けるよ うな傾向はみられず、その割合が低い地域や南側廊下自体が確認で きなかったところと、やや高い割合を示す地域があることから、一 部の地域における傾向であったと考えられる(表 5)。

\section{3 南側廊下校舎をもつ小学校の特徵と建設の経緯}

新築された小学校に南側廊下校舎のあるものはなかった。そこで、 南側廊下校舎をもつ小学校の建設経緯を踏まえ、その特徴を明らか にする。既往文献 ${ }^{1)}$ から北側廊下へ移行する時代であることから、 北側廊下はなく南側廊下のある小学校と、北側廊下と南側廊下の両

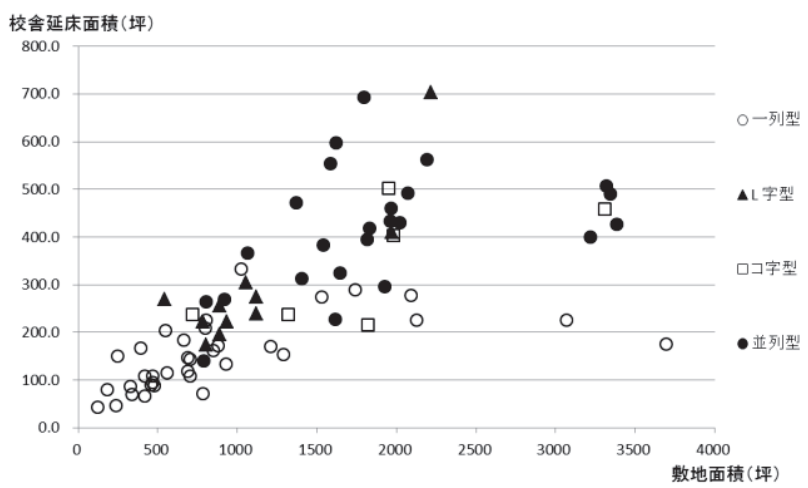

図 3 校舎形態による敷地面積、校舎延床面積

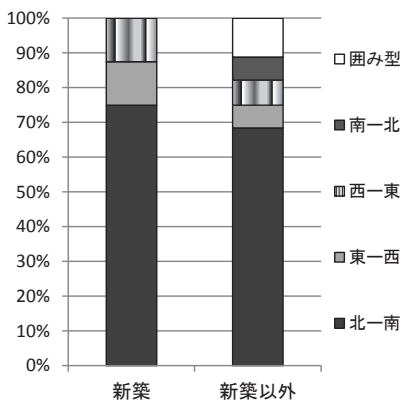

図 4 校舎-運動場の位置関係

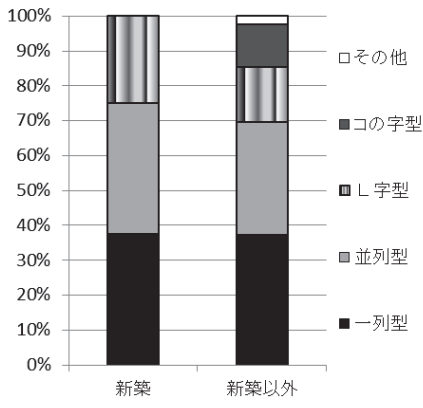

図 5 校舎形態
表 4 校舎の廊下位置による分類

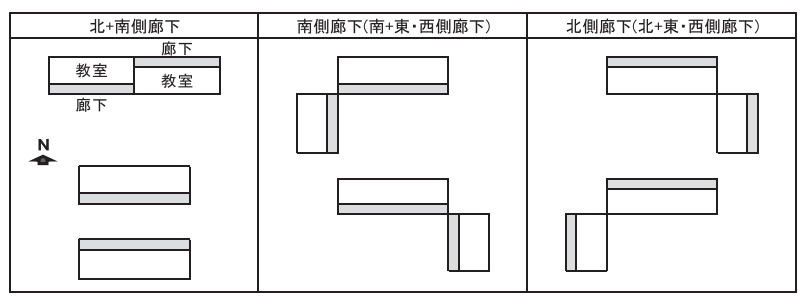

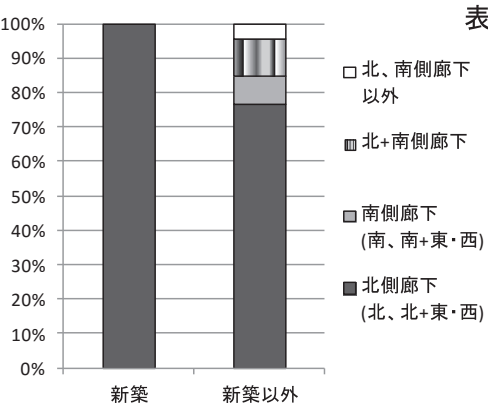

図 6 校舎の廊下位置
表 5 南側廊下のある小学校数

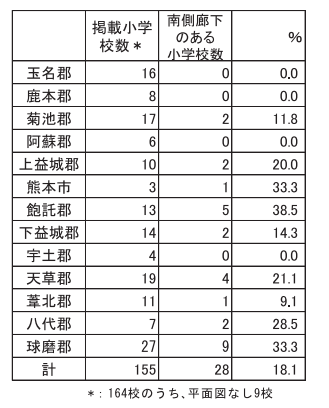

表 6 南側廊下主体型の小学校

\begin{tabular}{|c|c|c|c|c|c|c|c|c|}
\hline & 校舎形態 & 小学校名 (所在地域) & $\begin{array}{l}\text { 既存棟 } \\
\text { 建設年 }\end{array}$ & \begin{tabular}{|c} 
南㑡庭下 \\
校建設年
\end{tabular} & & 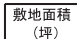 & \begin{tabular}{|c} 
延床面皘 \\
(坪)
\end{tabular} & $\begin{array}{c}\text { 校全一 } \\
\text { 逜動場 }\end{array}$ \\
\hline 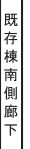 & -列 & $\begin{array}{l}\mid \text { 松高尋常小学校 (八代郡) } \\
\text { 五町尋常小学校 (鵤钎郡西里村) } \\
\text { 兔田尋常小学校 (球磨郡兔田村) } \\
\text { 中村尋常小学校 (天草郡) } \\
\text { 湯出小学校 (莘北郡) }\end{array}$ & $\begin{array}{l}\text { 明治 } 13 \text { 年 } \\
\text { 明治 } 26 \text { 年 } \\
\text { 明治 } 31 \text { 年 } \\
\text { 明治 } 39 \text { 年 } \\
\text { 明治 } 43 \text { 年 }\end{array}$ & 明治 44 年 & $\begin{array}{l}\text { 注16) } \\
\text { 注17) } \\
\text { 注18) } \\
\text { 注19) } \\
\text { 注20) }\end{array}$ & $\begin{array}{r}1118 \\
586 \\
2124 \\
887 \\
-\end{array}$ & $\begin{array}{r}239.5 \\
\text { (教室: } 94) \\
225.0 \\
\text { (教窒: } 91) \\
127.0\end{array}$ & $\begin{array}{l}\text { 北一南 } \\
\text { 北一南 } \\
\text { 北一南 } \\
\text { 北一南 } \\
\text { 南一北 }\end{array}$ \\
\hline 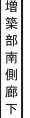 & $\begin{array}{l}\Rightarrow \text { L字 } \\
\Rightarrow \text { コの字 }\end{array}$ & $\begin{array}{l}\text { 福田尋常高等小学校 (上益城郡) } \\
\text { 渡寻常小学校 (球磨郡) } \\
\text { 坂瀬川尋常高等小学校 (天草郡) }\end{array}$ & $\begin{array}{l}\text { 明治 } 42 \text { 年 } \\
\text { 明治 } 24 \text { 年 } \\
\text { 明治 } 32 \text { 年 }\end{array}$ & $\begin{array}{l}\text { 大正 } 4 \text { 年 } \\
\text { 大正 } 5 \text { 年 } \\
\text { 明治 } 43 \text { 年 }\end{array}$ & $\begin{array}{l}\text { 注21) } \\
\text { 注22) } \\
\text { 注23) }\end{array}$ & $\begin{array}{r}981 \\
1054 \\
-\end{array}$ & $\begin{array}{r}{[288 \rightarrow 384]} \\
151 \rightarrow 304 \\
232.8\end{array}$ & $\begin{array}{l}\text { 東-西 } \\
\text { 西-東 } \\
\text { 北一南 }\end{array}$ \\
\hline \begin{tabular}{|l|} 
不 \\
明
\end{tabular} & $\begin{array}{l}\text {-列 } \\
\text { 並列 } \\
\text { L字 } \\
\text { L字 }\end{array}$ & $\begin{array}{l}\text { 敷川内尋常小学校 (八代郡) } \\
\text { 下益城高等小学校 (下益城郡) } \\
\text { 御所浦掌小学校 (天草郡) } \\
\text { 松尾西部尋常小学校（能託郡） }\end{array}$ & $\begin{array}{c}- \\
- \\
\text { 明治31年 } \\
-\end{array}$ & & & $\begin{array}{c}420 \\
- \\
544 \\
-\end{array}$ & $\begin{array}{l}- \\
- \\
269.5 \\
-\end{array}$ & $\begin{array}{l}\text { 南一北 } \\
\text { 北一南 } \\
\text { 北一南 } \\
\text { 北一南 }\end{array}$ \\
\hline
\end{tabular}


方がある小学校にわけ、前者を南側廊下主体型、後者を並立型とし

て考察を行う。

\section{1 南側廊下主体型の小学校の建設経緯とその特徵}

南側廊下主体型は 12 校で、いずれも県の中部もしくは南部の小学 校であった。延床面積は 300 坪未満ものがほとんどで、配置構成は 北側校舎・南側運動場のものが多いことなど全体の傾向と同様で、特 徵的な傾向はみられなかった。

建設年代及びその後の増改築の状況が確定できたもの は 8 校である。そのうち 5 校は建設当初から南側廊下校 舎で、その建設年代は明治 30 年以前が 2 校、同 30 年以 降は 3 校で、校舎形態は全て一列型であった。また、残 りの 3 校は建設当初、南北方向に長い一列型の校舎形態 で、廊下は東または西側に配され、その後増築された校 舎が南側廊下の形式で、建設年代はいずれも明治後期か ら大正前期にかけてであった(表 6)。

明治 30 年代以降、政府及び県が北側廊下を推奨してい るなか、数は少ないが、主に県の中部から南部にかけて 南側に廊下をもつ小学校が散見された。

\section{2 並立型の小学校の建設経緯とその特徵}

並立型 16 校のうち、建設年代及びその後の増改築の状 況が確定できたものは 10 校であった。その中で、既存校 舎が南側廊下で、その後の増築校舎が北側廊下になるも のが 7 校で、それとは逆に既存校舎が北側廊下で、増築 校舎が南側のものが 3 校みられた。前者はさらに増築の 方法により、増築部が既存校舎と一列になるものと、別 棟になるものに分けられる。また、後者は全て、増築部 は別棟である(表 7)。

既存校舎が南側廊下で増築部が北側廊下になる小学校 では、既存校舎の建設年代は明治 32 年の 1 校を除き 20 年代である。県が校舎の配置に関する指針で南向きを推 奨するが同 29 年、北側廊下が示される県令が同 33 年で あり、既存校舎の多くはそれ以前の建設で、北側廊下と なる増築部は明治 30 年以降であることから、指針に対応 していることがわかる。球磨郡の木上村木上尋常小学校 は明治 8 年創立で、西側部分の校舎は明治 24 年建設で南
側廊下であるが、東側部分の 2 階建校舎は大正 6 年の建設で北側廊 下の形式をとる (写真 1 , 図 7)。また、上益城郡の滝川尋常高等小学 校は明治 24 年創立で、敷地の北側に位置する同年建設の校舎は南側 廊下の形式をとるが、大正 4 年にその南に校舎が増築され、北側廊 下となる(写真 2 , 図 8)。

\section{表 7 並立型の小学校}

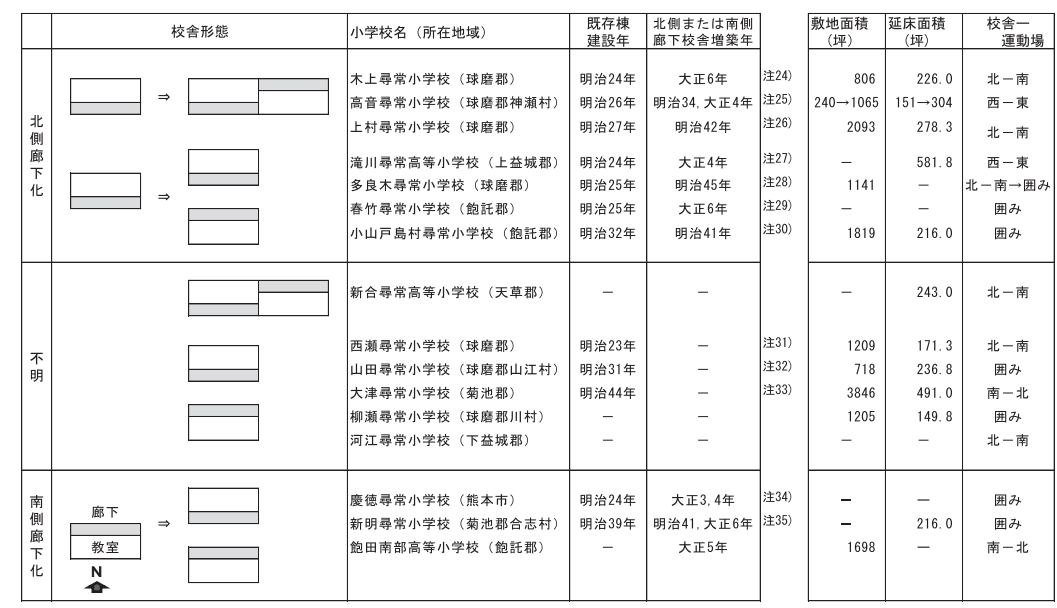

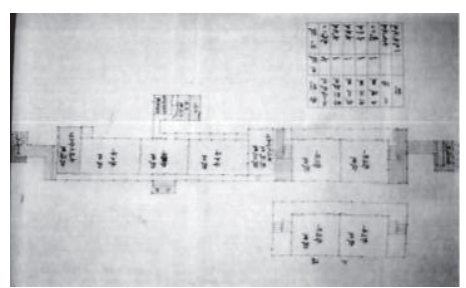

写真 1 木上尋常小学校平面図 (県政資料大正 4 年掲載)

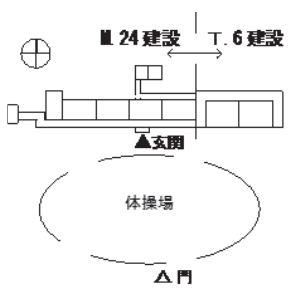

図 7 木上尋常小学校 略配置·平面図

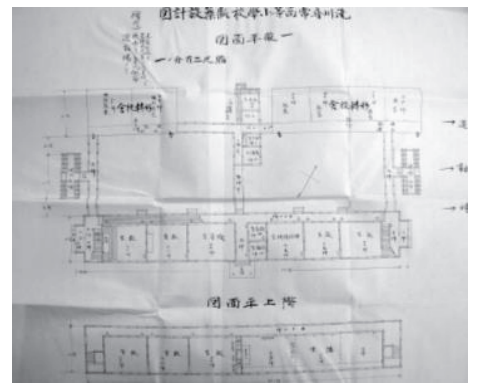

写真 2 滝川尋常高等小学校平面図 (県政資料大正 5 年掲載)

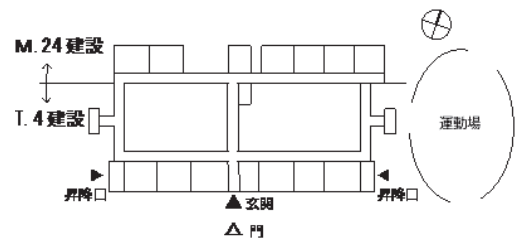

図 8 滝川尋常高等小学校 略配置·平面図

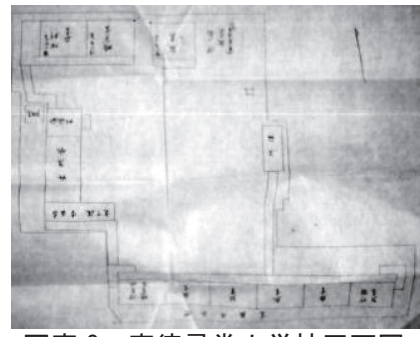

写真 3 慶徳尋常小学校平面図 (県政資料大正 5 年掲載)

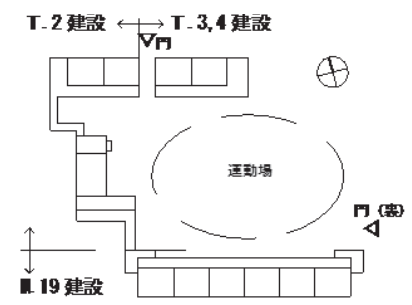

図 9 慶徳尋常小学校略配置·平面図

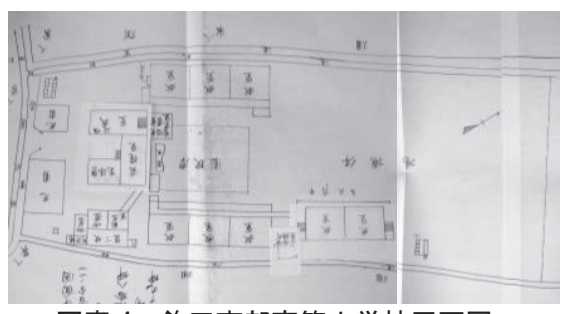

写真 4 飽田南部高等小学校平面図 （県政資料大正 5 年掲載）

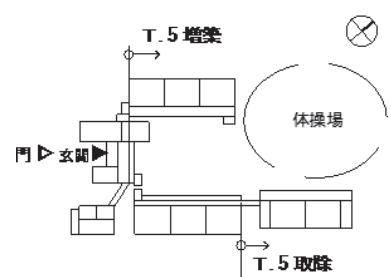

図 10 飽田南部高等小学校略配置·平面図

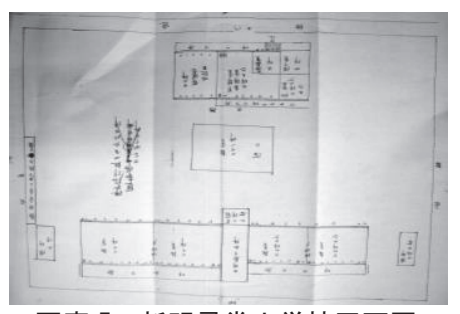

写真 5 新明尋常小学校平面図 (県政資料大正 6 年掲載)

$\oplus$

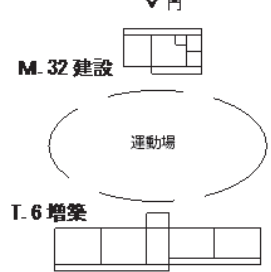

図 11 新明尋常小学校略配置·平面図 
一方、明治後期以降、増築校舎が南側廊下の形式をとる小学校が 3 校確認できた。熊本市の慶徳尋常小学校と飽託郡の飽田南部高等小 学校では、既存校舎が北側廊下の形式で敷地南側に位置し、運動場 や学校園をはさんで南側廊下の校舎が増築されている(写真 3 , 図 9 , 写真 4, 図 10)。また、菊池郡合志村の新明尋常小学校は、既存校舎 が北側廊下の形式で敷地の北側に位置し、明治 41 年にその東と南に 校舎が増築され、後者が南側廊下であった。大正 6 年には北と南の 校舎のみとなり、運動場をはさんだ配置構成になる (写真 5, 図 11)。

以上のことから、南側廊下主体型を含めて、地域的には熊本市及 びその周辺、並びに、県南地方において、明治後期以降も南側廊下 校舎が建設されていたことが確認できた。

\section{4 熊本市議会における小学校建築に関する指針と建設実態}

明治 30 年代の小学校建築の設計指針により、熊本県全体としては 南側から北側廊下への変更がみられる一方、数は多くはないが依然 として南側廊下の校舎が地域的には熊本市周辺と県南でみられた。 熊本市では明治 20 年代以降小学校建設に関する案件の審議が目立 つようになり、特に、政府が地域の実情に応じた施設計画を求め、 県でも詳細な規定をなくした大正期以降、児童数に対する小学校数 の不足と施設の老朽化も相まって、小学校の設備に関する議案が審 議されている(表 8)。

\section{1 大正期から昭和初期における指針と小学校の実態}

明治 20 年代では、主に小学校の修繥及び増築の予算に関する案件 で、空気の流通や採光などの衛生面、体裁としての立関、奉安所の 設置、並びに、教室の大きさが議案にあがっている。

明治 40 年代に入ると、市周辺の町や村が熊本市に合併されるのを 機に、小学校の再編・統合が審議の中心になる。県政資料で南側廊下 の割合が一番多かった飽託郡も、大正 10 年以降随時、熊本市に編入 される。大正 14 年 2 月 5 日から 17 日の議会では、小学校整理統合 に関する建議案が出され、その理由として『毎年学級数の増加に伴 ひ校舎の増築及敷地拡張の必要を生じつつあるの現況なるにその施 設方法たるや彌縫的計画に過ぎずして本市永遠の教育施設としては 頗る不十分なりと認む。』あり、3 月 31 日には熊本市小学校整理 臨時調查会の設置が可決され、学校の設置及び区域、並びに、その 設備が調査されることとなった注 ${ }^{35)}$ 。その後、昭和 3 年 2 月 28 日か ら 3 月 22 日の議会では、小学校の整理・合併とともに、小学校設備 に関し、『基礎工事はすべてコンクリートを施し、通風採光にも考慮 して、廊下などは南廊下を原則とする』とあり、南側廊下を奨励し ていたことが示されている。

調査会の設置から議会における報告までの 3 年間の経緯に関して は、史料がなく不明であるが注 ${ }^{36)}$ 、その間の市の動向を当時の新聞 記事から把握する (表 9$)$ 。大正 14 年 7 月中に 2 回の調查会が開かれ、 同年 12 月 7 日付の九州日日新聞によると、学校整理案の決定が報告 されている。その中で “学校の設備標準”として校地や校舎の規程 が示されているが、校舎の廊下に関する項目は紙面上にはなかった。 また、その翌 15 年 9 月 10 日付の九州新聞注 37) では学校整理の大体 方針として先の “学校の設備標準”が再び示されている。ところで、 同日付の九州日日新聞によると、熊本市では新たに学校建築調査会 を設け、同月 12 日付の同新聞では『…学校建築の根本方針を決定す る筈であるが建築様式の統一は勿論教室の構造から空の取方、空硝
子の寸法にいたるまで専ら児童を本位として全部統一し…』とある。 同月 16 日付の同新聞では “学校建築標準”という記事があるが、そ の内容は主に構造・材料に関するもので、空に対しては『腰壁は二尺 五寸とし空は三尺五寸に縮め欄間を二尺五寸のスリ硝子として其下 より室内カーテンを取りつけて総て览童の取扱に便すること』の項 目だけであった。その後、昭和 3 年 3 月 4 日付の九州新聞で “今市 会に提出された熊本市学校整理根本案”の記事において『‥通風採 光は特に考慮を払ひ廊下等も凡て南廊下を原則としている…』、 議会での内容が改めて確認できたが、この間の動向の記述はなかっ た。明治 42 年の文部省の訓令「学校校舎ノ建築八実用ヨ主トスヘキ 件」以降、訓令の意図とは異なり学校建築の類型化はますます進ん だという指摘があるが注 38 、熊本市では小学校建築に対する検討が

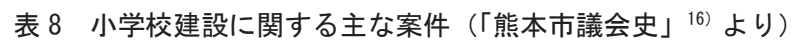

\begin{tabular}{|c|c|c|c|}
\hline 開催年 & 月日 & 審議·諮問項目 & 審議内容 \\
\hline 明治23年 & 7月17日 & \begin{tabular}{|l} 
五福小学校修緗費を本年度市 \\
税予借金より支出る件
\end{tabular} & 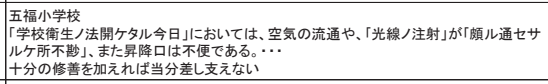 \\
\hline 明治23年 & 7月17日 & \begin{tabular}{|l} 
手取小学校增筑費を本年度市 \\
祱予借金より支出する件
\end{tabular} & 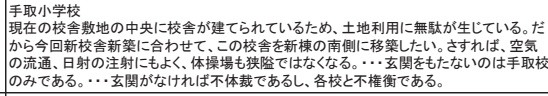 \\
\hline 明治25年 & 7月 $27 \sim 30$ & $\begin{array}{l}\text { 日能本高等諸学校二聖影奉安所 } \\
\text { 設惪二関ス儿儿諮問 }\end{array}$ & \\
\hline 明治27年 & $\begin{array}{l}\text { 7月27 } \\
\text { 8月1日 }\end{array}$ & 予算関係案 & 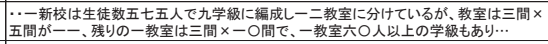 \\
\hline 大正10年 & 4月19日 & & 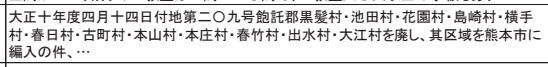 \\
\hline 大正12年 & 2月20 23日 & & 慶德小学校の営䌍·敖地拡張計画等にこついて䝷疑応答 \\
\hline 大正14年 & 2月5 17日 & 予算審議 & 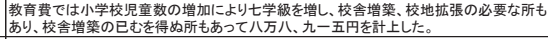 \\
\hline 大正14年 & 2月5 17日 & 小学校整理较合に関する建莪 & 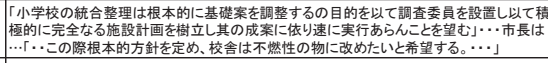 \\
\hline 大正14年 & 3月31日 & $\begin{array}{l}\text { 議題六O号熊本市小学校整理 } \\
\text { 監時調查会設置規定,件 }\end{array}$ & 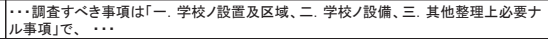 \\
\hline \multirow{2}{*}{ 大正15年 } & \multirow{2}{*}{ 2月19 28日 } & 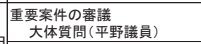 & 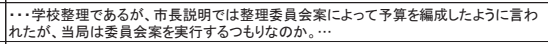 \\
\hline & & (市長) & 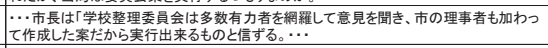 \\
\hline 昭和 3 年 & $\begin{array}{l}\text { 2月28〜 } \\
\text { 3月22日 }\end{array}$ & 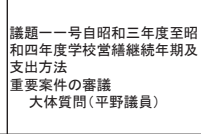 & 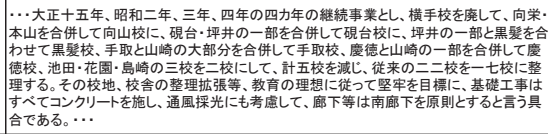 \\
\hline \multirow[b]{2}{*}{ 昭和 10 年 } & \multirow[b]{2}{*}{ 2月13日 } & \begin{tabular}{|l} 
重要案件の審譜 \\
一般質問(打出莪員) \\
\end{tabular} & 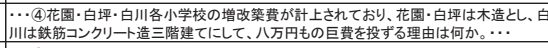 \\
\hline & & (市長) & 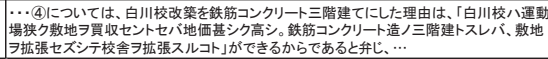 \\
\hline
\end{tabular}

表 9 熊本市の学校整理調査委員会等に関する新聞記事

\begin{tabular}{|c|c|c|c|}
\hline 揭載日時 & 新聞各 & 記事見出し、内容要約 & 記事报粋 \\
\hline 大正 14.2 .5 & 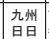 & \begin{tabular}{|l|} 
震内小事会が学校の根本本的整理案 \\
\end{tabular} & 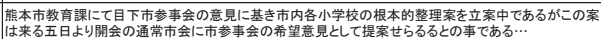 \\
\hline 大正 14.7 .4 & 九州 & 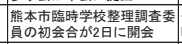 & 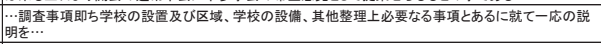 \\
\hline 大正14.7.19 & 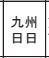 & 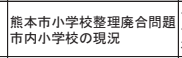 & 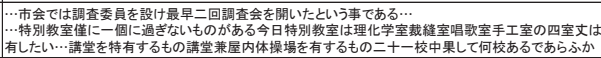 \\
\hline 大正14.10.24 & 同上 & 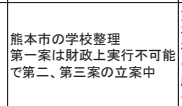 & 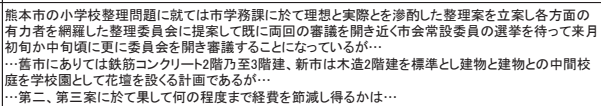 \\
\hline 大正14.12.7 & 同上 & 決定した市の学校整理 & 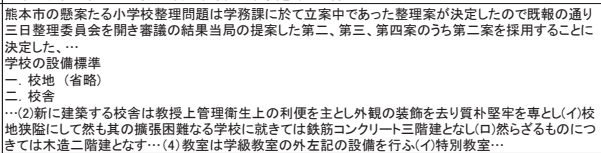 \\
\hline 大正15.9.10 & 九州 & 能本市学校整理の大体方針 & 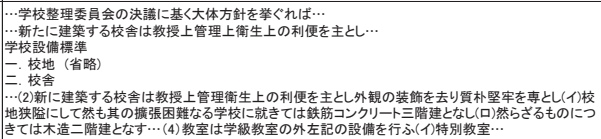 \\
\hline 大正15.9.10 & 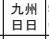 & $\mid$ & 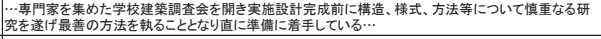 \\
\hline 大正15.9.12 & 同上 & 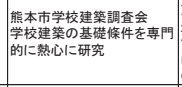 & 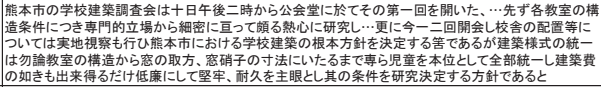 \\
\hline \multirow[t]{2}{*}{ 大正15.9.16 } & \multirow[t]{2}{*}{ 同上 } & \multirow[t]{2}{*}{ 市の学校建築標蕉 } & 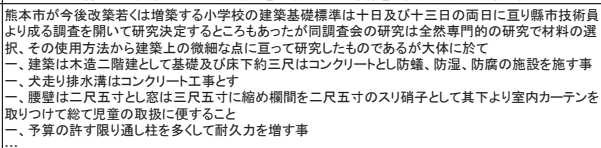 \\
\hline & & & 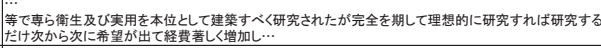 \\
\hline 昭和 3.3 .4 & 九州: & 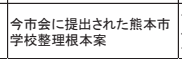 & 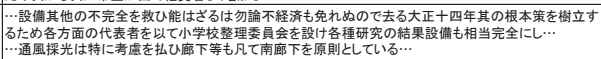 \\
\hline
\end{tabular}


なされていた。

こうした議会での審議及び市の検討を踏まえ、大正後期から昭和 初期にかけて 17 校が校舎の改変を行っており、主にそれぞれの学 校史をもとに校舎の建設実態を把握する(表 10)。先の昭和 3 年の議 会までに建替えや増改築等が行われていなかった 13 校は、昭和 2 $\sim 4$ 年度までの完成予定が示されている。その後、概祇昭和 10 年頃 までには何らかの工事が行われており、一番遅い古町小学校では昭 和 13 年に新校舎が竣工している。建替えや増築後の概要が確認で きたのは 13 校で、その中の 4 校は鉄筋コンクリート造 3 階建校舎 が新築され、残りは木造の主に 2 階建校舎であった。鉄筋コンクリ 一ト造が選択された小学校はいずれも都市部で、敷地の拡張が難し く、こうした条件の小学校に対しては、鉄筋コンクリート造にする ことで 3 階建とし、増加する生徒数に対応していたようである注39)。 廊下位置に関しては、確定できた 6 校全ての小学校において、南側 廊下校舎のみ、または校舎が複数の場合、そのひとつが南側校舎で あり、市の指針が適用されていることが窥える。県が大正 2 年の改 正で、小学校建築に対して関係当事者の裁量に任せるという方針を とり、その後熊本市では、南側廊下の校舎を推奨、実践したことが 確認できた。

\section{2 熊本市立出水小学校の校舎の変遷}

熊本市立出水小学校における創立当初からの校舎の変遷を捉える (表 11)。同小学校は現在、熊本市出水に立地するが、明治期は合併 前の託麻郡で、今村、国府村、長溝村の 3 つの村のそれぞれの小学 校を起源とする。明治 17 年にそれらが合併され、校名は三友小学校 と改称され、現在地とは異なる 380 坪の敷地に、間口 10 間、奥行 2 間半、 1 間半の下屋付きで瓦莫の 2 階建校舎と 2 間半 $\times 3$ 間の事務室 が建てられた。また、同 20 年には間口 10 間、奥行 3 間の瓦葺平屋 建の校舎が敷地の南側に増築されている注 40 )。廊下に着目すると、

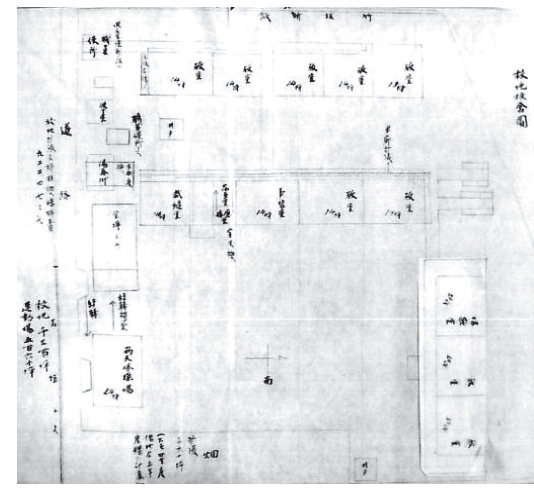

写真 6 出水尋常小学校平面図（県政資料大正 4 年掲載）
表 10 昭和 3 年市議会で案件に挙がった小学校の建設経緯

\begin{tabular}{|c|c|c|c|c|c|c|}
\hline \multicolumn{3}{|c|}{\begin{tabular}{c|c|}
$\begin{array}{l}\text { 昭和3年 市議会録 } \\
(2 / 288 \sim 22)\end{array}$ \\
\end{tabular}} & \multirow{2}{*}{ 建設過程 } & \multirow{2}{*}{ 構造 } & \multirow{2}{*}{ 廊下位置 } & \multirow{2}{*}{ 参毿考 } \\
\hline & 校名 & 完成予定年度 & & & & \\
\hline $\begin{array}{l}\text { 新 } \\
\text { 横手 } \\
\end{array}$ & -新 & 既に完成 & 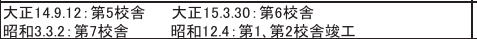 & $\begin{array}{l}\text { 床造 } \\
2 \mathrm{~F}\end{array}$ & - & \\
\hline 俱手 & 向山 & $\begin{array}{c}\text { 1年度までた } \\
\text { 完成 }\end{array}$ & 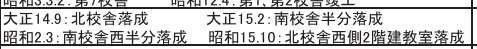 & $\begin{array}{l}\frac{2 F}{\text { 木造 }} \\
2 \mathrm{~F}\end{array}$ & - & 34),35) \\
\hline 硯台 & 硯台 & 3年度 & 眧和5.11: 現在地1二新校舎 昭和6.2: 全焼 昭和6.7: 新校舍竣工 & - & - & 36,.377 \\
\hline 评开 & 黒髮 & 2年度 & 昭和 2 : 校舎拡張(276坪) 昭和 15 : 木造校舎改築 & 木造 & - & 38) \\
\hline 手取 & 挈取 & 3年度 & 眧和9.11: 第4、5校舎付属舎增新築 昭和 10.11 : 校舎改築 & $\begin{array}{l}\text { 条造 } \\
2 \mathrm{~F}\end{array}$ & 南、北、東 & 39) \\
\hline 山崎 & 慶德 & 既に完成 & 大正 15.9 : 銠筋コンクリート校舎誜エ & $\begin{array}{l}\mathrm{RC} \\
3 \mathrm{~F}\end{array}$ & - & 31) \\
\hline 池田 & 池田 & $\begin{array}{l}1 \text { 年度までた } \\
\text { 完成 }\end{array}$ & 昭和2.9 : 改笑移転 & - & - & 40) \\
\hline 島崎 & 花園 & 4 年度 & 昭和11.3: 新䇣校舎落成 & $\begin{array}{l}\text { 木造 } \\
1.2 F\end{array}$ & - & 41) \\
\hline 春日 & 春日 & 3年度 & 昭和 3.3 : 第1校舎竣工 昭和 3.12 : 第2 2 校舎竣工 & - & - & 42) \\
\hline 大江 & 大江 & 3年度 & 昭和2.6:2階建校舎新笑 & $\begin{array}{l}\text { 条造 } \\
2 \mathrm{~F}\end{array}$ & 南 & 43) \\
\hline 壸川 & 壸川 & 4年度 & 昭和7: 本館鉄筋 3 階建谩工 & $\begin{array}{l}\mathrm{RC} \\
3 \mathrm{~F}\end{array}$ & 南 & 44) \\
\hline 白川 & 白川 & 4年度 & 昭和1 11.4: 鉄筋本館階建延 507 坪竣工 & $\begin{array}{l}\mathrm{RC} \\
3 \mathrm{~F}\end{array}$ & 南 & 45) \\
\hline 本荘 & 本暀 & 4年度 & 昭和2.6: 校舎2階建 180 坪增築 昭和 3.10 : 本館 2 階建 120 坪新築落成 & $\begin{array}{l}\text { 木造 } \\
2 \mathrm{~F}\end{array}$ & - & 46) \\
\hline 春竹 & 春竹 & 4年度 & 昭和7.2:2階建校舎150坪増築 & $\begin{array}{l}\text { 柰造 } \\
2 F\end{array}$ & - & 288,47) \\
\hline 古町 & 古町 & 4年度 & 昭和 13.7 : 新校舎完成 & - & - & 48),49) \\
\hline 出水 & 出水 & 4年度 & 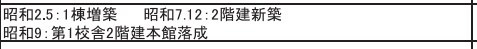 & $\begin{array}{l}\text { 条造 } \\
2 F\end{array}$ & 南 & 50),51) \\
\hline 五福 & 五福 & 4年度 & 昭和5.11: 鉄筋3階校舎完成 & $\begin{array}{l}\mathrm{RC} \\
3 \mathrm{~F}\end{array}$ & 南 & \\
\hline
\end{tabular}

図面上では縁とあるが、明治 17 年の校舎では南側に、増築された校 舎では北側に、どちらも運動場に向いて配されている。

現在地に移転するのは明治 36 年で、900 坪の敷地に木造平屋建の 2 棟からなる校舎が建設され、延床面積は 229.75 坪であった注 41$) 。$ 校舎は運動場の北側に位置し、2 棟が南北に平行に並ぶ並列型で、 廊下は北に配され、教室は南面している。明治 30 年代に政府や県が 指導している校舎の配置、校舎形態、教室の南面化など、それに沿 った平面計画がなされていることがわかる。明治 39 年には南側に校 地を 300 坪拡張し、主に運動場に供し、同 42 年には校地の東側に、 既存の校舎と直交するように 2 階建の校舎が増築され、生徒の増加 に対応している注 42) (写真 6)。

託麻郡が熊本市と合併するのは大正 14 年であるが、同じ年に明治 36 年建設の校舎の中の北の棟が撤去され、建替えられる。校舎はそ れまで同様、並列型の配置構成を成すが、廊下位置は南に変更され ている。その後、昭和 3 年と 4 年に校地が拡張され、既存の古い校 舎を撤去し、昭和 6 年、9 年に校舎が建設されている注 43$)$ 。それらは 配置構成上、南北に並行に配されるが、廊下位置は南側に変更され るという共通の特徴を持つ。

つまり、出水小学校では、明治中頃までは南側廊下または運動場 に向いて廊下が配されていたが、明治 38 年の移転を機に、県の指針 に従うように北側廊下となり、さらに、大正 14 年以降の建替えでは 南側廊下へと変更されており、熊本市への合併とも相まって、市の 指針に対応していることが確認できた。

表 11 熊本市立出水小学校の校舎の変遷

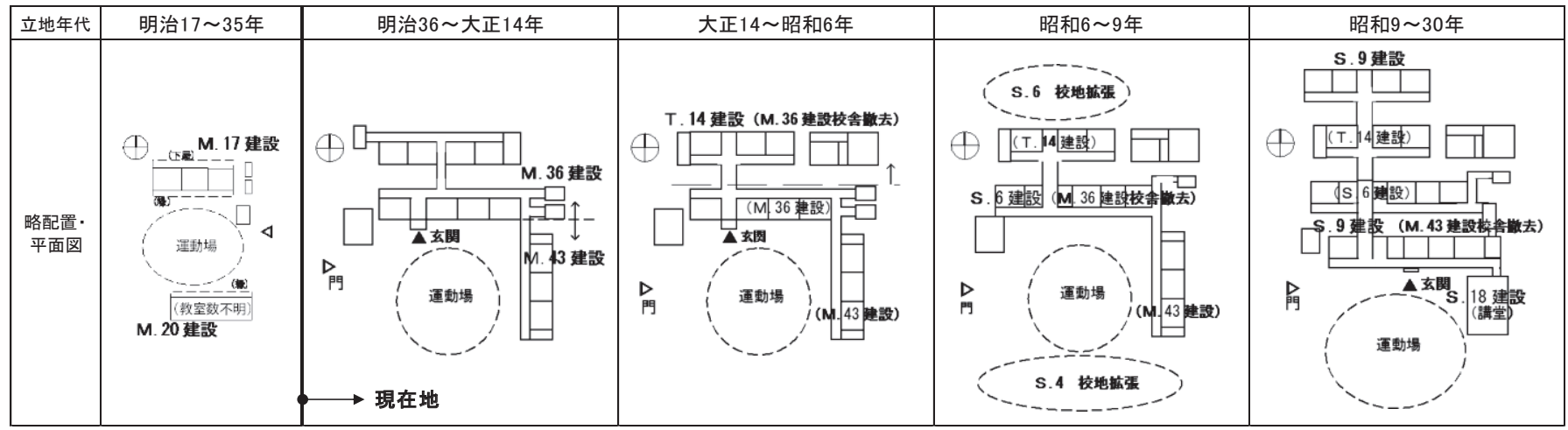




\section{5 まとめ}

政府及び県の小学校建築に対する指針、並びに、熊本市議会にお ける小学校建設に関する案件と、明治 44 年から大正 7 年の県政資料 及び学校史における図面との比較・分析により、以下の結果を得た。 ・小学校建築に対する熊本県の指針は明治 25 年から示され、配置構 成や校舎形態に関しては、政府よりいち早く規準を設けている部 分もあり、校舎の廊下に対しては、明治 33 年の県令で北側廊下を 推奨している。また、明治 42 年の文部省の訓令において地域の実 情に応じた施設計画を求めたことと期を同じくして、県でも明治 41 年には、教室の大きさに関して地域の状況を配慮した改正を行 い、大正 2 年にはそれまでの規定をなくし、関係当事者の裁量に 任せるという方針をとった。一方、熊本市では大正 14 年に小学校 整理臨時調查会が設置され、校地や校舎の指針が設定され、また、 翌 15 年には新たに学校建築調査会を設け、主に構造・材料に関す る指針を示している。さらに、昭和 3 年、議会に提出された熊本 市学校整理根本案では南側廊下が推奨されていた。

・県政資料の配置及び平面図から、校舎の配置構成は北側校舎·南側 運動場が時代とともに割合が高くなり、校舎形態は一列型が高い 割合を示し、並列型も時代とともに増加するなど、政府や県の指 針に沿った傾向がみられた。

・校舎の廊下位置に関しては、県が明治 33 年に北側廊下を明確に規 定たこともあり、既存の南側廊下校舎に北側廊下が増築される事 例がみられるなど、県全体としては時代とともに北側廊下の校舎 が高い割合を示した。一方、南側廊下を主張していたと言われる ほどに、その割合は全体としては高くなかった。ただ、熊本市を 中心とした地域や県南部において、南側廊下の形式をとるものが 比較的多くみられたことから、地域性があったとも考えられる。

・熊本市では、昭和 3 年、南側廊下を推奨しており、平面図等が確 認できた昭和以降建設された全ての小学校において、南側廊下の 校舎がみられた。熊本市立出水小学校では、明治 20 年以前に建て

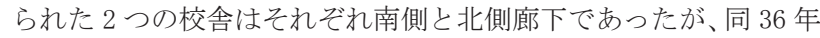
建設の校舎では北側廊下に、大正 14 年以降建設の校舎では南側廊 下の形式をとっており、政府と県、並びに、市の指針に対応して いることが確認できた。

南側廊下の指針の背景は確認できず今後の課題であるが、地域の 実情に応じた施設計画を求められながら類型化がますます進んだと いわれる時代に、熊本市では小学校建築に対して検討がなされ、新 たな指針が提示され、実践されていた。

\section{参考文献}

1）青木正夫：建築計画学 8 学校 I, 丸善株式会社, 1976.4.30

2）菅野誠, 佐藤譲：日本の学校建築, 文教ニュース社, 1983.7

3）青木正夫：文部省は学校建築の発展に何をしてきたか，建築雑誌，第 1326 号, 1992.4

4）大場修：滋賀県下における明治前期の小学校校舎について - 明治期の小 学校校舎に関する地方史研究その 1 -, 日本建築学会近畿支部研究報告集, pp. 961 964， 1993.6

5）大場修，荒井麻理：明治前期奈良県下の小学校校舎をめぐる動向－小学 校校舎の地方史 I - , 日本建築学会計画系論文集 第 473 号, pp. 139 $147, \quad 1995.7$

6）大場修：京都旧番組小学校の校舎プラン - 小学校校舎の地方史 II - , 日 本建築学会計画系論文集 第 512 号，pp. 245～252， 1998. 10

7）竹下昌一, 飯淵康一, 永井康雄：山形朝日町県に現存寸る明治期小学
校建築について - 小規模 2 階建校舎の平面形式に関する一考察 - , 日本建 築学会大会学術講演梗概集, F, pp. 1449 1450， 1993.9

8）竹下昌一，飯淵康一，永井康雄，大槻隆史：岩手県における明治期小 学校建築の平面計画について - 生徒控所および廊下を中心として - , 日本 建築学会東北支部研究報告集 58 号, pp. 47〜 50, 1995.6

9）竹下昌一, 飯淵康一, 永井康雄：岩手県における明治期小学校建築の 平面形式について, 日本建築学会大会学術講演梗概集, F-2, pp. 57〜 58, 1995. 8

10）石田周次，飯淵康一，永井康雄，西野敏信：宮城県における明治期 小学校建築について - 生徒控所を持つ校舎の平面形式と分布 - , 日本建築 学会大会学術講演梗概集，F-2， pp. 33〜 34， 1997.9

11）西野敏信, 飯淵康一, 永井康雄 : 岩手県における明治期小学校建築の 平面概要, 日本建築学会東北支部研究報告集, pp. 53 58, 2000.6

12）川島智生：近代京都における小学校建築，ミネルヴァ書房，2015.3

13）山本昌宏, 北野隆：八代市立代陽小学校の鉄筋コンクリート造校舎に

ついて, 日本建築学会研究報告. 九州支部. 3 計画系, pp. 421 424, 1997. 3

14）熊本大学教育学部附属小学校：百年の歩み, 1975.10 .1

15）熊本縣公文類纂：土地地種變換 學校，熊本県立図書館蔵

16）熊本市議会事務局：熊本市議会史 戦前編，熊本市議会 1989.3

17）熊本縣教育会：熊本縣教育史 上巻，中巻，下巻，臨川書店，1975. 10.30

18）熊本県：熊本県布達便覧，明治 $32 \sim 44$ 年，熊本県立図書館蔵

19）熊本県教育会八代郡支会：八代郡史，1927.8

20）西里小学校百周年記念実行委員会：にしざと創立百周年記念誌， 1976.5

21）免田小学校創立百周年記念編集委：免田小学校百周年記念文集，1976.3

22）天草教育振興協議会：天草教育史， 1975.12

23）湯出小学校百周年記念誌編集：創立百周年記念誌, 1975.2

24）上益城郡長：上益城郡誌，1921

25）球磨郡教育支会：球磨郡誌，1941.8

26）人吉球磨退職校長会：郷土の学校沿革史 第 2 部 沿革の概要, 1997.5

27）神瀬小学校百年祭実行委員会：神瀬校百年誌， 1975.4

28）春竹小学校百周年記念事業実行委員会：春竹, 1973.12

29）託麻東小学校百周年記念事業実行委員会：百年託麻東, 1975.2

30）大津小学校創立百周年記念行事期成会：創立百周年記念誌， 1975.9

31）慶徳小学校：慶徳百年, 1976. 10

32）旭志村史編纂委員会：旭志村史， 1993.9

33）一新小学校創立百周年記念事業期成会：一新百年のあゆ夕， 1976.3

34）向山小学校広報部： 向山 90 周年記念誌, 1967.2

35）向山小学校創立百周年記念事業期成会：向山百年, 1977. 3

36）碩台小学校：碩台の百年, 1974.9

37）碩台小学校：碩台読本, 1993. 10

38）黒髪小学校：記念誌黒髪, 1975. 11

39）城東校百周年記念誌編集委員：城東校 (手取·山崎·城東) 百年のあゆみ, 1981. 1

40）池田小学校：池田校創立百周年記念誌， 1974.2

41）花園小学校創立百周年記念事業期成会：花園の百年, 1979.7

42）春日小学校創立百周年記念事業期成会：春日の歴史， 1973.6

43) 大江小学校 : 大江読本, 1995.3

44）壳川小学校記念誌編集委員会：㚄川の百年，1978

45）白川小学校創立 80 周年記念実行委員会：白川小学校創立 80 周年記念誌, 1990.2

46）本荘小学校創立百周年記念事業期成会：本荘， 1979.3

47）春竹小学校創立九十周年記念事業実行委員会：春竹, 1963.3

48）古町小学校：わたしたちの古町， 1976.10

49）古町小学校：古町の歴史 古町校創立百周年記念誌， 1976.6

50）林田喜熊：出水校八十年史， 1954.12

51）熊本市立出水小学校：出水校百年史, 1975.11

52）五福小学校創立百周年記念事業期成会：五福百年, 1977.6

注

注1）参考文献 2), p 165

三島通良（1866～1925）は明治·大正期の医師で、学校衛生の創始者であ る。埼玉県出身で、明治 21（1889）年に帝国大学医科大学卒業後、同 24 （1992）年から文部省の委嘱により全国の学校衛生の調査を行い、改善の 指針を示した。同 28 (1896) 年には文部省総務局学校衛生課主事となり、 東京高等師範学校では学校衛生学の講義を行っている。著作に「学校衛 生学」などがある。 
注2）参考文献 3), p 51

注3）参考文献 4), p 961

注4）参考文献 13)， p 422 平面図とともに、校舎の 1,2 階ともに南側廊下であることが述べられて いるだけで、その背景等に関する記述はない。

注5）参考文献 14)， pp. 619〜620

昭和 4 年 11 月に竣工した校舎の普通教室に関して、『床、空枠とも木製 で古く、南廊下、北側教室であるため照度が低く $\cdots$ という記述が平面 図とともにある。

注6）参考文献 17）中巻, p 561

注7）参考文献 16）上り、明治 20 年代以降、小学校の修繥・増築の諮問案や予 算案の検討や奉安所の設置などが審議されており、特に、大正 10 年以降、 生徒の増加と熊本市への町村合併により校区の変更など小学校の整理統 合及び学校設備の検討が議案として挙がっている。

注8）分教場 21 校、方位が確定できなかった 11 校は除いている。

注9）参考文献 17）中巻, p 149

注10）参考文献 2), pp. 165 184

注11）九州日日新聞社が明治 21 年〜昭和 17 年にかけて発行していた新聞

注12）参考文献 17）下巻, pp. 52〜56

注13）参考文献 2), p 229

注14）参考文献 17）より、明治 11 年の小学校数は同年の学事年報に掲載の明 治 4 年から同 11 年に設立された小学校数の和 (上巻, pp. 443〜 461)、明 治 19 年の分は支校を含んだ小学校数 (中巻, pp. 104〜105)、明治 33 年 の分は尋常小学校、尋常高等小学校、高等小学校の総数 (中巻, p 562)、 大正 2 年の分は同年 1 月に県から視学会議に示した資料からのものであ る(下巻, pp. 54〜 56)。

注15）明治 5 年当時の白川県と八代県の区分を参考に大きく北と南に大きく 2 つに分け、前者は更に現在の県北と県央に該当する郡に分け、後者は 球磨郡が江戸時代には相良藩であったことから独立して扱った。

注 16）参考文献 19)， pp. 148～151

注 17）参考文献 20)， pp. 63〜65

注 18）参考文献 21）， pp. 5〜6

注 19）参考文献 22）， pp. 230～231

注 20）参考文献 23), pp. 38〜 45

注 21）参考文献 24，，p368

注 22）参考文献 25，，p435、参考文献 26）， p 84

注 23）参考文献 22）， pp. 511～513

注 24）参考文献 25)， pp. 427〜 428

注 25）参考文献 26)， pp. 98～100、参考文献 27) , pp. 51 61

注 26）参考文献 26)， pp. 44 47

注 27）参考文献 24）， p365

注 28）参考文献 25)， p422

注 29）参考文献 28), pp. 1 18

注 30）参考文献 29), pp. 1〜3

注 31）参考文献 25，，p434

注 32）参考文献 25)， pp. 431～432

注 33）参考文献 30), pp. 12〜14

注 34）参考文献 31）， pp. 202～251

注 35）参考文献 32$) ， \quad$ pp. 1233 1236

注 $35 ） 大$ 大正 14 年 4 月 14 日付、市告示第三十一号

注 36）参考文献 16）の元となる市議会録は、該当する時代のものが昭和 28 年 の大水害で消失している。

注 37）九州新聞社が明治 43 年〜昭和 17 年にかけて発行していた新聞

注 38）参考文献 2)， pp. 485〜486

注 39）参考文献 16)，p1215

注 40）参考文献 51)， pp. 15～18

注 41）参考文献 51)， pp. 27〜28

注 42）参考文献 51)， p 34

注 43）参考文献 51)， pp. $45 \sim 49, \quad$ pp. 52〜 53 


\title{
BUILDING GUIDELINE OF KUMAMOTO PREFECTURE AND CITY AND THE CONSTRUCTION ACTUAL CONDITION
}

A study on the elementary school building with a south-side corridor

\section{Kazuhide AKIMOTO*}

* Prof., Dept. of Architecture, Faculty of Engineering, Sojo University, Dr. Human Env.

\begin{abstract}
Most of elementary school buildings have a corridor in the north side. This form was established by government lead after the Meiji middle. It is indicated that Kumamoto prefecture insisted on the corridor on the south strongly against this current.

In the Kumamoto prefectural government data, the document and drawing of the notification of an elementary school from Meiji 44 to Taisho 7 are left. And in the Kumamoto municipal assembly, the bill about elementary school construction was discussed at the same time.

In this study, it is the aim to clarify the actual condition and the background of the elementary school building with a south-side corridor in Kumamoto prefecture from Meiji to the early stages of Showa. Therefore, the following four viewpoints were set up.
\end{abstract}

1. The characteristic in the guideline of an elementary school building of Kumamoto prefecture: comparison of guideline of the government and Kumamoto prefecture of Meiji and Taisho period

2. The characteristic in the arrangement composition, form, and corridor position of a school building: analysis of arrangement and plan in prefectural government data

3. The characteristic of the elementary school building with a south-side corridor: construction process, and arrangement and plane composition in history of school

4. The actual condition of the elementary school in Kumamoto city after the Taisho: guideline of city by municipal assembly data, and arrangement and plane composition in history of school

The following results were obtained by analysis.

1) As for the guideline of Kumamoto prefecture of the elementary school, the standard was shown about arrangement composition and school building form in Meiji 25 earlier than the government.

2) About the arrangement composition of the school building, the type of school building on the north and playground on the south increased as time passes, and about the school building form, an one-line type indicated the high rate to be about 40 percent at any time, and the parallel type was increasing, so the tendency according to the guideline of the government and prefecture was seen.

3) About the corridor position of the school building, although it is said that Kumamoto prefecture insisted on the south-side corridor in school buildings, numbers of that building were few and their rate of a north-side corridor increased with a time. However, since there were many school buildings with a south-side corridor at the southern prefecture area and centering on Kumamoto city, it is thought that there was regionality of corridor on the south.

4) After the Meiji 40s, the Kumamoto prefecture changed to the guideline in which he leaves it to judgment of each corporation. Kumamoto city recommended the south-side corridor in Showa 3, and accordingly school building with a south-side corridor increased after that. 